\title{
Addressing Energy Efficiency by Periodical Energy Audits
}

\author{
Wes Grebski \\ The Pennsylvania State University, USA \\ Michalene Grebski \\ Northampton Community College, Monroe Campus, USA \\ Agnieszka Czerwińska-Lubszczyk \\ University of Technology and Humanities in Bielsko-Biała, Poland \\ Dominika Jagoda-Sobalak \\ Opole University of Technology, Poland
}

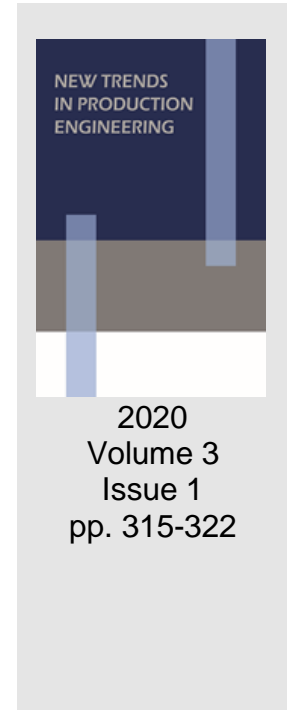

Date of submission to the Editor: 11/2019

Date of acceptance by the Editor: 01/2020

\section{INTRODUCTION}

Energy is indispensable to human existence, and its need is on the increase daily due to technological advancement. Buildings require cost-effective and sustainable solutions (Adewale et al., 2018). The transition of householders towards optimal energy use in the residential sector has proved to be challenging. There are various techniques like for example: energy performance certificates, prompts, norm appeals, commitments, economic incentives and disincentives, feedbacks, community-based initiatives, benchmarking, goal setting and gamification, energy labels and energy auditing (Iweka et al., 2019). Energy auditing is a process for accessing energy usage by individual energyconsuming devices on a residential or commercial scale. An energy audit is a method for determining the most cost-effective measures that improve energy efficiency (von Knorring, 2019). After the energy audit is completed, a diagram can be created which defines the energy consumption by individual energy consuming devices, e.g. refrigerator, washer, dryer, television, heating system, hot-water heater, etc. An energy savings plan follows the energy auditing process (Grebski \& Cai, 2010a). First it focuses on low hanging fruits, e.g. installation of high efficiency lightbulbs, high efficiency appliances, etc. Insulating the building and changing windows/doors is usually very costly... high hanging fruits. They are addressed as secondary measures due to a longer payback time.

\section{ENERGY AUDIT}

The energy auditing process can be conducted by a professional energy auditor or by the residents/owners of the property. Hiring an energy auditor can be costly, so many people are willing to conduct the energy audit themselves. The basic equipment used in an energy audit is a power monitor. The power monitor 
can be purchased for approximately $\$ 100$ or borrowed from a local municipality or power company. The power monitor is plugged into an electrical outlet. It measures the amount of energy transferred from that electrical outlet to the appliance. This method measures the energy consumption by the individual appliances which are plugged directly to the receptables. It is necessary to make a detailed list of the electrical appliances and devices/gadgets, such as air conditioners, computers, etc. (Grebski \& Cai, 2010b). The collected data from the power monitor needs to be recorded in the table. Table 1 contains real data for an energy audit conducted by one of the publication's authors.

Table 1 Energy Used by Existing Appliances

\begin{tabular}{|l|c|c|}
\hline \multicolumn{1}{|c|}{ Device } & $\begin{array}{c}\text { Energy Usage/Hour } \\
\text { (kilowatt x hour) kWh }\end{array}$ & $\begin{array}{c}\text { Energy Usage/Month } \\
\text { (kilowatt x hour) kWh }\end{array}$ \\
\hline Electric Washer & 2.25 & 67.5 \\
\hline Electric Dryer & 3 & 90 \\
\hline Air Conditioner & 1.1 & 264 \\
\hline Refrigerator & .17 & 122 \\
\hline Microwave & 1 & 12 \\
\hline Computer & .05 & 18 \\
\hline Stove & 2 & 120 \\
\hline Dishwasher & 1.4 & 42 \\
\hline Toaster & .9 & 3.5 \\
\hline Electric Water Heater & 5 & 400 \\
\hline $\begin{array}{l}\text { Small Appliances } \\
\text { (iron, toaster oven, etc.) }\end{array}$ & .5 & 10 \\
\hline Lights & 2 & 360 \\
\hline
\end{tabular}

Total Energy Usage/Month:

$\underline{1509 \mathrm{kWh}}$

The data is from that author's primary residence. The energy usage per hour was measured by using a power monitor.

The exception to this was lights and the water heater because those devices are wired directly (no receptacles). The power consumption for those devices was calculated by multiplying power capacity (printed on the device) by the approximate time of usage per day. There is a need to especially inspect the energy usage by older appliances.

Monthly energy usage was calculated using this equation.

Energy Usage/Month = Energy Usage/Hour $x$ Hours of Usage/Month

An energy audit for lights was conducted as follows:

- Count the number of lightbulbs in each room and determine their power (e.g. $60 \mathrm{~W}, 100 \mathrm{~W}$, etc.).

- Determine and record the total power (in watts) for each room in the building. Use the following formula.

(number of bulbs per room in the building) $\times$ (watts per bulb) $=$

(Total watts per room in your residence)

- Convert watts to kilowatts according to the following formula.

(Total watts) $\times .001=($ Total kilowatts $)$ 
- Calculate the energy used by the lights in each room according to the following formula.

(Total kilowatts $(\mathrm{KW})$ per room in your residence $) \times($ Hours per day used $)=$

(Total Kilowatt hours (KWh) per day per room in your residence)

- Calculate the energy used by the lights in the entire building/residence by adding the energy used by the lights in the individual rooms.

Other things to consider during your residential (home) lighting audit as follows: On the day of the audit, were any lights turned on in unoccupied rooms? Yes Are light levels too bright, adequate, or too dim in any spaces? No Were any other lights, such as desk lamps, used in any rooms? № Are there movement sensors in any rooms? No Are lights fixtures clean to provide the best light? Is light available from windows not exposed to direct sun?

\section{ENERGY USED BY MODERN ENERGY-EFFICIENT APPLIANCES}

Energy labels are seals or energy efficiency rankings usually found on white goods and appliances. These labels attract the attention of consumers to the energy information of the product and helps the consumers to make better choices when acquiring appliances. (Iweka et al., 2019) Modern energy-efficient appliances have an energy-efficient sticker as shown in Fig. 1.

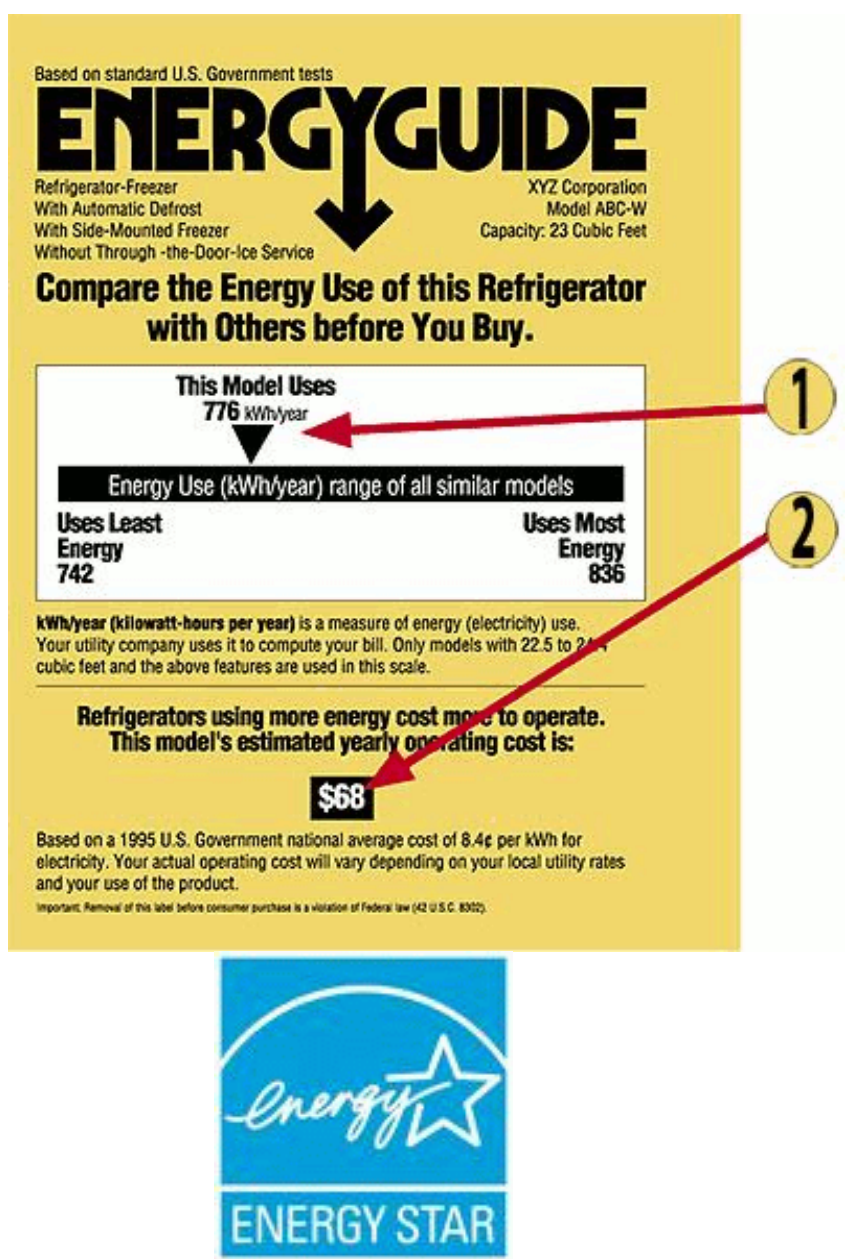

Fig. 1 Modern appliances energy-efficiency sticker used in United states of America 
Table 2 contains the energy usage by modern appliances. The yearly energy usage was taken from the energy-efficiency stickers. The cost of the appliances includes the price, sales tax and delivery. This data was collected from an appliance distributor.

Table 2 Energy usage by modern appliances

\begin{tabular}{|l|c|c|c|}
\hline \multicolumn{1}{|c|}{ Appliance } & $\begin{array}{c}\text { Energy Used } \\
\text { Yearly (kWh) }\end{array}$ & $\begin{array}{c}\text { Energy Used } \\
\text { Monthly (kWh) }\end{array}$ & $\begin{array}{c}\text { Cost } \\
\text { to Purchase }\end{array}$ \\
\hline Electric Washer & 109 & 9.1 & $\$ 600$ \\
\hline Air Conditioner (wall unit) & 890 & 74.2 & $\$ 350$ \\
\hline Refrigerator & 505 & 42.1 & $\$ 1400$ \\
\hline Dishwasher & 194 & 16.2 & $\$ 650$ \\
\hline Electric Water Heater & 4700 & 391.7 & $\$ 350$ \\
\hline Freezer & 357 & 29.8 & $\$ 600$ \\
\hline
\end{tabular}

Appliances have energy efficiency stickers. The yearly energy usage was taken from the energy efficiency sticker.

The cost of the appliance includes the price with sales tax and delivery.

\section{ENERGY SAVINGS}

Due to today's rising energy prices, the efficient use of energy consumed by facilities is possible with the energy savings that can be made by updating the technology, optimizing and constant controlling. (Hadra et al., 2019). To calculate the expected energy savings, it is necessary to compare the present energy use of existing appliances with the energy use of modern energy-efficient appliances (Grebski \& Dudeck, 2013). This comparison of energy use and energy savings is shown in Table 3 . The total energy use of the present appliances is $1509 \mathrm{kWh}$. The total energy saving per month is $646.4 \mathrm{kWh}$

Table 3 Comparison of energy use and energy savings

\begin{tabular}{|l|c|c|c|c|c|}
\hline \multicolumn{1}{|c|}{ Appliance } & Age & $\begin{array}{c}\text { Energy } \\
\text { Consumption } \\
\text { (kWh) }\end{array}$ & $\begin{array}{c}\text { Modern } \\
\text { Consumption } \\
\text { (kWh) }\end{array}$ & $\begin{array}{c}\text { Modern } \\
\text { Cost }\end{array}$ & $\begin{array}{c}\text { Excess } \\
\text { (kWh) }\end{array}$ \\
\hline Electric Washer & 15 & 67.5 & 9.1 & 600 & 58.4 \\
\hline Electric Dryer & 15 & 90 & 80 & 500 & 10 \\
\hline Air Conditioner & 10 & 264 & 74 & 350 & 190 \\
\hline Refrigerator & 20 & 122 & 42 & 1400 & 80 \\
\hline Microwave & 12 & 12 & 10 & 200 & 2 \\
\hline Computer & 1 & 18 & 18 & 800 & 0 \\
\hline Stove & 15 & 120 & 120 & 600 & 0 \\
\hline Dishwasher & 20 & 42 & 16 & 650 & 26 \\
\hline Toaster & 5 & 3.5 & 3.5 & 40 & 0 \\
\hline Electric Water Heater & 5 & 400 & 380 & 350 & 20 \\
\hline Small Appliances & 10 & 10 & 10 & 200 & 0 \\
\hline Lights & 10 & 360 & 100 & 50 & 260 \\
\hline Total & - & $\mathbf{1 5 0 9}$ & $\mathbf{8 6 2 . 6}$ & - & $\mathbf{6 4 6 . 4}$ \\
\hline
\end{tabular}

Comparing the use of energy by the existing appliances with the energy used by newer energy- efficient appliances, it is easy to see where the potential 
for energy savings exists. In this sample energy audit, the energy savings for individual appliances have been calculated. (Dudeck \& Grebski, 2011).

If all appliance in the house (lightbulbs, air conditioners, refrigerator, washer, dishwasher) were replaced with energy efficient appliances, energy consumption would decrease from $1509 \mathrm{~kW} / \mathrm{h}$ to $862.6 \mathrm{~kW} / \mathrm{h}$. The energy use reduction would be $42 \%$.

\section{Payback Time}

The payback time was defined as the time needed to generate energy saving to pay for new appliances. The payback time was calculated as follows:

Calculating the payback time for the replacement incandescent light bulbs with energy efficient light bulbs is as follows:

Lights:Replacement Wattage:

$\underline{100}$

Number of Light bulbs:

$$
\begin{gathered}
\text { Cost }=\frac{(\# \text { of bulbs }) \times(\text { price per bulb })}{\text { Cost }=20 \times \$ 2.50} \\
\text { Cost }=\$ 50.00
\end{gathered}
$$

Monthly cost of energy by incandescent light bulbs is $360 \mathrm{kWh} \times 0.1 \$ / \mathrm{kWh}$ $=\$ 36.00$

Monthly cost of energy used by energy efficient light bulbs is $100 \mathrm{kWh} x$ $0.1 \$ / \mathrm{kWh}=\$ 10.00$

Monthly Energy Savings = Cost of energy for old bulbs -

Cost of energy for new bulbs

Monthly Energy Savings = \$36.00 $-\$ 10.00$

Monthly Energy Savings $=\$ 26.00$

Payback Time $=$ Cost of light bulb replacement/Monthly Energy Saving

Payback Time $=\$ 50 / \$ 26$

Payback Time $=1.9$ months

Appliances: Total Replacement Cost $=$ Appliance Cost

(including sales tax and delivery)

Amount of Energy Currently Used = Monthly Energy Consumption

(Present Appliance/Measure by Power Monitor)

Amount of Energy Used by Modern Appliance = Monthly Energy Consumption

(Energy Star Appliance/Energy Guide Sticker)

Excess energy is calculated using the following:

Excess Energy = (amount of energy currently used) -

(amount used by modern appliances)

Time endured until money is saved (for one appliance at a time) is calculated using the following:

(cost of new appliance $) /($ former monthly cost $)-($ new monthly cost $)=$ \# of months

Look at the column with the energy excess use. Compare the use of energy by the existing appliances with the energy used by newer energy efficient appliances. It is easy to see where the potential for energy savings exists (Grebski, et al., 2014). In this sample energy audit, the energy savings for air 
conditioners, refrigerator, washer and dishwasher have been calculated. The payback time has also been calculated for those four appliances.

\section{Air Conditioner Payback Time}

- Cost of the energy used by the old air conditioner:

$$
264 \mathrm{kWh} \times 0.1 \$ / \mathrm{kWh}=\$ 26.40
$$

- Cost of energy used by new energy efficient air conditioner:

$74 \mathrm{kWh} \times 0.1 \$ / \mathrm{kWh}=\$ 7.40$

- Payback time $=$ Cost of New Energy-Efficient Air Conditioner/Monthly Saving of Energy:

$$
\text { Payback time }=350 /(\$ 26.40-\$ 7.40)=18 \text { months }
$$

\section{Refrigerator Payback Time}

- Cost of the energy used by the old refrigerator:

$122 \mathrm{kWh} \times 0.1 \$ / \mathrm{kWh}=\$ 12.20$

- Cost of energy used by new energy efficient refrigerator:

$42 \mathrm{kWh} \times 0.1 \$ / \mathrm{kWh}=\$ 4.20$

- Payback time $=$ Cost of New Energy-Efficient Refrigerator/Monthly Saving of Energy:

Payback time $=1400 /(\$ 12.20-\$ 4.20)=175$ months $(14.5$ years $)$

\section{Washer Payback Time}

- Cost of the energy used by the old washer:

$$
67.6 \mathrm{kWh} \times 0.1 \$ / \mathrm{kWh}=\$ 6.70
$$

- Cost of energy used by new energy efficient washer

$9.1 \mathrm{kWh} \times 0.1 \$ / \mathrm{kWh}=\$ 0.91$

- Payback time $=$ Cost of New Energy Efficient washer/Monthly Saving of Energy:

Payback time $=\$ 600 /(\$ 6.70-\$ 0.91)=103$ months $(8.6$ years $)$

\section{Dishwasher Payback Time}

- Cost of the energy used by the old dishwasher:

$42 \mathrm{kWh} \times 0.1 \$ / \mathrm{kWh}=\$ 4.20$

- Cost of energy used by new energy efficient dishwasher:

$16 \mathrm{kWh} \times 0.1 \$ / \mathrm{kWh}=\$ 1.60$

- Payback time = Cost of New Energy-Efficient dishwasher/Monthly Saving of Energy:

Payback time $=\$ 650 /(\$ 4.20-\$ 1.60)=250$ months $(20.8$ years $)$

\section{Environmental benefits}

Energy audits are very important for protect environment (Wu, 2019). It could be prepared for very energy-intensive buildings like hospital (Hwang et al., 2019), sports facilities (Kamahina et al., 2019), hotels (Nocera et al., 2019), shipping companies (Knorring, 2019), historic buildings (Mazzola et al., 2019), construction project (Zhang \& Zhang, 2019) and also for our houses with operate 
24 hours, 365 days a year. The environmental impact based on the energy saved can be calculated by using an environmental impact calculator which can be accessed through the following website. http://www.epa.gov/cleanenergy/energy-resources/calculator.html.

\section{CONCLUSIONS}

The energy-auditing process can be a very effective method of promoting an energy-saving culture (Grebski, Cai \& Anwar, 2010). The understanding of the energy-consumption process by individual appliances in the household is helping in planing a more efficient use of those appliances. Replacing the existing and often outdated appliances can lead to a significant saving of almost $50 \%$ of the present energy consumption. A decrease in the energy use is making an important and significant progress in protecting the environment and reducing smog. Energy saving does not normally decrease the quality of life of the residents. Energy efficiency is the most cost-effective method of lowering energy use and protecting the environment. Alternative and sustainable forms of energy should be considered after the energy efficiency is already addressed.

Energy audit, with used "do-it-yourself" procedure are focus on environmentally, economically and socially effective, which contributes to the implementation of the concept of sustainable development.

\section{REFERENCES}

Adewale, A.A., Adekitan, A.I., Idoko, O.J., Agbetuyi, F.A. and Samuel, I.A. (2018) 'Energy audit and optimal power supply for a commercial building in Nigeria', Cogent Engineering, Vol. 5, pp. 1-18.

Dudeck, K. and Grebski, W. (2011) 'New General Engineering Program with Alternative Energy and Power Generation Track at Penn State', ASEE New England Regional Conference Proceedings. American Society of Engineering Education.

Grebski, W. and Cai, S. (2010a) 'Meeting Educational Needs of the Sustainable Energy Industry', Proceedings of the International Conference of Engineering Education ICEE-2010.

Grebski, W. and Cai, S. (2010b) 'Promoting Energy Sustainability Education through Outreach Projects', Proceedings of Eighth LACCEI Latin American and Caribbean Conference for Engineering and Technology Conference.

Grebski, W. and Dudeck, K. (2013) 'Portable Photovoltaic Laboratory for In-service Teacher Workshops', Conference Proceedings: 2013 Annual Conference American Society for Engineering Education.

Grebski, W., Cai, S. and Anwar, S. (2010) 'Development of a General Engineering Degree with an Alternative Energy and Power Generation Focus', Proceedings of European Congress on Sustainability and Energy.

Grebski, W., et al. (2014) 'Recruitment of Engineering Students through CommunityBased Programs', 2014 Latin America-Caribbean Conference on Engineering and Industry.

Hanra, M., Hergül, A.S., Kaya, D., Eyidoğan, M., Kiliç, F.C. and Özdemir, N.C. (2019) 'An Energy Audit and Optimization in Bar Mill Annealing Furnace', International Journal of Ecosystems and Ecology Science, Vol. 9(1), pp. 5-15.

Hwang, D.K., Cho, J., and Moon, J. (2019) 'Feasibility Study on Energy Audit and Data Driven Analysis Procedure for Building Energy Efficiency: Bench-Marking in Korean Hospital Buildings', Energies, Vol. 12, pp. 1-18. 
Iweka, O., Liu, S., Shukla, A. and Yan, D. (2019) 'Energy and behavior at home: A review of intervention methods and practices', Energy Research \& Social Science, Vol. 57, pp. 1-11.

Kamahina, R.S., Shamsuvaleeva, E.S. and Daibova, E.V. (2019) 'Green Certification to Achieve Sustainable Development Goals', Revista San Gregorio, Vol. 32, pp. $1-6$.

Mazzola, E., Mora, T.D., Peron F. and Romagnoni P. (2019) 'An Integrated Energy and Environmental Audit Process for Historic Buildings', Energies, vol. 12, pp. 1-18.

Nocera, F., Giuffrida, A., Trovato, M.R. and Gagliano, A. (2019) 'Energy and New Economic Approach for Nearly Zero Energy Hotels', Entropy, Vol. 21, pp.1-15.

Von Knorring, H. (2019) 'Energy audits in shipping companies', Transportation Research Part A, Vol. 125, pp. 35-55.

Wu, K. (2019) 'Research on the energy audit from the perspective of environmental protection', IOP Conf. Series: Earth and Environmental Science, pp. 1-6.

Zhang, X. and Zhang, X. (2019) 'Environment Protection and Resources Saving of the Industrial Construction Projects: The Role of Audit', IOP Conf. Series: Earth and Environmental Science, pp. 1-5.

\begin{abstract}
.
The publication focuses on assessing the energy efficiency in residential and to some extent commercial applications. An energy audit is always the first step in addressing energy efficiency. The purpose of the publication is to present the benefits of using an energy audit. It explains a "do-it-yourself" procedure for an energy audit. The publication also focuses on calculating the potential energy saving by updating low-efficiency electric appliances with high-efficient alternatives. The environmental benefits of addressing the energy efficiency of households is also being discussed. An energy audit using a "do-it-yourself" procedure focuses on the economic, ecological and social impact to environment. The energy audit contributes to the implementation of the concept of sustainable development in our day by day life.
\end{abstract}

Keywords: Energy audit, energy efficiency, energy saving 